\title{
The Ashgate Research Companion to Border Studies
}

\author{
A.-L. Amilhat Szary \\ Université Joseph Fourier Grenoble, Institut de Géographie Alpine, Grenoble, France \\ Correspondence to: A.-L. Amilhat Szary (anne-laure.amilhat@ujf-grenoble.fr)
}

Wastl-Walter, D.: The Ashgate Research Companion to Border Studies, Ashgate, Farnham, 728 pp., ISBN-13: 978-0-7546-7406-1, €132.99, 2011.

The publication of a Border Studies Companion marks the maturation point of a field of social sciences which has followed an expanding trajectory since its refoundation in the 1990s. Doris Wastl-Walter, director and founder of the Ashgate Border Regions Series, built up this compendium in view of her broad understanding of the evolution of thinking in this field and the result is very successful, although one could miss the fact that she does not personally sign any chapter of the book. The volume is made of 31 chapters which globally manage to tackle worldwide case studies (with very interesting Asian cases, from Central Asia to Singapore, passing by Myanmar - but almost no reference to African borders) with, almost always, a very useful theoretical insight. One of the limits of this overview is the very limited cartographic illustration that the volume offers: few maps which offer almost no semiological input to allow for further interpretation. The richness of the volume resides however in the very diverse origin of its authors, from a disciplinary as well as from a geographical point of view, and in the capacity of its editor to have allowed for the intellectually fruitful collaboration of confirmed and young scholars.

The first part of the Companion, dedicated to theoretical insights, does not reveal its best: the renowned authors gathered here offer only a synthesis of past writings, insisting on the ambivalence of contemporary debordering/rebordering processes. Texts by T. Zhurzhenko on Memory, by S. Kron on Transmigrants are good surprises since both highlight important epistemological questions by the way of problematic analysis of original regional cases, notably when S. Kron elaborates on the intersectionality questions that borders raise. The second part elaborates on the central role of the state and nations in the power relations which are expressed at/by the borders. Both chapters by J. Scott (on EU expansion) and V. Kolossov (on post-Soviet boundaries) con- tribute to fill in a gap of the book - the historical background on border studies and the retrospective analysis of past fundamental geopolitical texts. It is followed by a third part on border enforcement. It mixes discussions on the changes in border regimes, with some very interesting cases which stress the complexity of multi-level understanding of borders (E. Manero on the transnational dimension of Latin American borders) as well as the rhetoric dimensions of barriers (the meta-border between Koreas, by V. Gelezeau). The increasing numbers of barriers on international borders is not however tackled from its material dimension.

This compendium's added value may be more explicit in its second half, which elaborates on the complex links between identities and territorialities in border regions. Part IV is devoted to the exclusion processes that border tracing implies, completing the discussion on nation building (in part II) with original texts on Central Asia (Mongolian Kazakhs by A. Diener and Persian-Iranian borders by P. Mojtahed-Zadeh). The following section (part V) is dedicated to the impact that borders conserve on everyday lives, even in a world of flows. It paradoxically allows for texts that tackle governance issues from this mundane point of view: the collective piece on Singapore's hinterland is one of the most successful here. The volume continues with a part on Crossing Borders (VI) and on Creating Neighbourhoods (VII), two ways of addressing borderlands and crossborder processes. The final part (VIII) concerns the interactions with nature at the border. The chapter on maritime border, by C. Schofield, is placed here but could have fit elsewhere. It mirrors the issue of aerial limits, which only appears here as a side question in A. J. Williams' text on the use of aviation by the US Air Force at certain borders. In this interesting collection of texts on border territorialities, one misses the fact that migration issues may not be present enough, especially the violence that border regimes impose on vulnerable individuals. 
The impression of a general reading of this Companion is optimistic: the vitality of border studies and the richness that changes in border regions will continue to offer reasons for further analysis. One might miss here a conclusion: border studies now constitute an intellectual capital which it is essential to mobilize in order for them to contribute to a stimulating renewal of spatial thinking. For that purpose, after showing that borders are everywhere, it is essential to develop on the changes in their territorialization, through which they no longer appear as linear devices. 